\title{
Assessing the Social-emotional and Adaptive Behavior Scores of Bayley-IIIScales, for Normal Egyptian Infants and Toddlers
}

\author{
Eman Fathy Mohamed Nofal (1), Rabab Elsayed Hassan(2), Mohamed Reda Bassiouny
}

(3), Sahar Farouk Hashem (4)

(1) Nurse Specialist at Mansoura University Children Hospital (MUCH) (B.SC Nursing), (2) Professor of Pediatric Nursing and head of Pediatric Nursing department Faculty of Nursing Mansoura University, (3) Professor of Pediatrics/Neonatology Faculty of Medicine Mansoura University, (4) Lecturer of Pediatric Nursing Faculty of Nursing Mansoura University

\begin{abstract}
Background : Early assessment of the child's developmental skills especially socialemotional and adaptive behavior skills is very important for early treatment and preventing problems. TheBayley-III scales are a worldwide valid tool for assessment of the children 's different developmental skills.This study aimedtoassess the social-emotional and adaptive behavior scores of Bayley-III scales, for normal Egyptian infants and toddlers. Method:Across-sectional comparative design was used Setting :The study was performed at the neonatal intensive care unitfollow-up clinic and the Staff Day Work nursery both affiliated to Mansoura University Children Hospital .Subjects : a convenience sample of all available young children ranged in age 3 months to 42 months and 16 days of both genders )n=140.(Tools:tool (I):structured interview questionnaire sheet developed with ؛ Part (1 :(characteristics of the participated infants/toddlers .Part (2 :(characteristics ofthe participated children's parents'tool (II :(The researcher has adopted and used twointerview questionnaires of the Bayley-III scales of Infant and Toddler Development * Third Edition :(1) Social-emotional scale questionnaire and (2) Adaptive behavior scale questionnaire.Results :This study demonstrated that the social-emotional scale of the Bayley-IIIhadahighmean row score and mean composite score which exceeded the USA scores.Conclusion :The results suggested that the social-emotional scale and the adaptive Behavior scale of the Bayley-III can be feasible instruments for assessment of the Egyptian children'sdevelopment.Recommendations:An adapted translated version of the Social-emotional and Adaptive behavior Scalescanhelp in improving and contributing to the research and clinical field.

Keywords: Adaptive Behavior development, Bayley-III, Developmental assessment, InfantSocial-emotional development, Toddler
\end{abstract}




\section{Introduction}

Infancy and early childhood are periods of developmental change, as children start to experience more independence in the physical and social environment. Through these new interactions with the world around them, children develop a sense of personality and self-relationship, as well as awareness of culture and its practices, including forming healthy attachments to others and moral assessments of their own and others' Behaviors(National Research Council, 2015).

Through early childhood, children move from infancy to toddlerhoodanddifferent developmental skills are attained, and their social and emotional competence is profoundly changed and forms the basis of their mental health. Childhood is the period in which the skills of self-conception, selfregulation, emotional control, and empathy, as well as a deeper understanding of interpersonal interactions and receptive and expressive communication skills, are developed (Shulman, 2016).

The early positive experiences organize the children's brain to have the needed ability, skills, and confidence to participate in satisfying and positive relationships and experiences. The development of social and emotional skills in early childhood affects all aspects of children's lifelong learning and development, as it develops skills such as thinking, planning, and decision making. These skills are a protective aspect for present and future mental health and wellbeing. Children who experience normal social-emotional skills are likely to get better outcomes than children who are less qualified(Conkbayir, 2017).
Kirchner, Martens and Andridge (2016) clarified that adaptive Behavior is a broad domain of development, refers to the child's ability to act independently in the environment. In other words; the daily activities required for personal and social selfsufficiency are carried out in a variety of life situations, including self-care such as dressing and bathing, community mobility, home maintenance, building up and maintaining relationships, and feelings and communication needs and feelings. The successful development of adaptive skills depends on the successful development of other developmental skills. From birth to 12 months, aninfant can suck with smooth, coordinated movements, place both hands on a bottle or breasts, swallows strained food, eats semi-solid foods, hold own bottle or spoon, chew and bites on toys, and sleeps 12-14 hours (Kramer, Coster, Kao, Snow \&Orsmond, 2012).

Early recognition of children with delayed development is very important seeing as early intervention can eliminate or minimize cognitive, Behavioral, educational, and social problems later in life. Thepurpose of the structured assessment of a child's development isto clarify the breadth and depth of the status of a child's development.Children have rates of development, so it is vital to differentiate those who are within normal from those who follow a pathological progression(Spittle, Orton, Anderson, Boyd, \& Doyle, 2015). The American Academy of Pediatrics (AAP) advises screening for children 'sdevelopment and Behaviors during scheduled followupvisits(Singh, Yeh \& Blanchard, 2017). 
The Bayley-III scales of Infant and Toddler Development, Third Edition (Bayley-III / BSID III), is the greatestbroadlyassessment tool to be used, it can identify early signs of delays and possible disabilities and also provide suggestions about symptoms of developmental disorders (Yi, Sung\& Yuk, 2018). The Bayley-III contains three main scales which are; the cognitive scale,the language scale; the expressive communication subtest, and the receptive communication subtest. Besides, the motor scale with two subtests; the fine motor subtest and the gross motor subtest (Logsdon, 2018).

Furthermore, two extra scales are depending on the parent report. The first is the social-emotional scale, which asks caregivers about a child's Behaviors as the social responsiveness and imitation. The second is the adaptive behavior scale that seeks to adapt to the demands of daily life, including communication, selfcontrol, follow-up, and get along with others. (Torras-Mañá, Gómez-Morales, González-Gimeno, Fornieles-Deu\& Brun-Gasca, 2016).

The Bayley-III scales structure allows examiners to manage each of the five scales independently of each other. Each scale and sub-test can be performed and ended up scoring effectively and accurately. In regards, such methods of assessment may promote observations of the child's Behavior(Weiss, Oakland \& Aylward, 2010). The social-emotional and adaptive Behavior scalesevaluate the child through questionnaires to be accomplished by the caregiverMadaschi, Mecca, Macedo, \& Paula, 2016).

Significance of the study

Assessing children's development is a new area in nursing research that may help in the assessment of anticipatory guidance in diagnosis and design a care plan for children with neurodevelopmental delay. Moreover, confirming the validity of the socialemotional scale and the adaptive Behavior scale of Bayley-III scales in Egypt like other foreign countries as the United States, through estimating a local valid normative score will be a base for the normal range of Bayley-III score for the Egyptian infants and toddlers and to be a reference for using it in the future.

\section{Aim of the study}

The study aimed to assess the social-emotional and adaptive Behaviorscores of Bayley-III scales, for normal Egyptian infants and toddlers.

\section{Research questions}

- What are the scores of the socialemotional and the adaptive Behavior of Bayley-III scales for Egyptian infants and toddlers?

- WillEgyptian infants and toddlers achieve the same norms that have been confirmed among their peers in other countries like the United States?

Subjects and Method

Research design: A crosssectional comparative design was usedin thisstudy.

Settings: The study was performed in thefollow-up clinic of the neonatal intensive care unit (NICU) and the Staff Day Work Nursery affiliatedto Mansoura University Children Hospital (MUCH).

Subjects: the present study included a convenience sample of all available infants and toddlers in age ranged from 3 months to 42 months and 16 days of both gender $(n=140)$.

Tools of data collection: the researcher used two tools for data collection as the following:

Tool (I): A structured interview questionnaire sheet: It was advanced by 
the researcher and concerned with the participants' demographic characteristics. It included two parts; Part (1): Characteristics of infants/toddlers who participated in the study; which are the date of birth, age in months and days, gender, and birth order.

Part (2):Characteristicsofthe parents accompanied the participated children; which are the parents' age in years, level of education, residence, occupation, family income, marital status, andthe number of children in the family.

Tool (II): Bayley-III scales of Infants and Toddlers Development, Third Edition (Bayley-III): the researcher adopted and used in the current study. It included2interview questionnaires:

- The social-emotional scale questionnaire: Consisted of 35 items, which measures how well children had met certain socialemotional milestones for their ages and.It evaluated children's workable emotional skills, which include self-regulation and involvement in the universe; ability to convey needs, interact with others and build relationships; and then use emotional messages to solve problems.

- Theadaptive Behavior scale questionnaire: This scale measured the important Behaviors that a child displays at home and in other settings, it included 10 skill areas, which consisted of 241 items, to evaluate the child's autonomous display of the needed skills in normal daily life.

\section{- Method}

Official permission was obtained by submission of official letters issued from:

- The Dean of Faculty of Nursing, Mansoura University to get approval for conducting the study.

- The manager of Mansoura University Children Hospital (MUCH) to get approval for collecting data from the Staff Day Work Nursery at MUCH.

- The head of the Neonatal Intensive Care Unit (NICU) department to get approval for conducting the study at the follow-up clinic affiliated to the NICU.

\section{Ethical considerations}

- Official permission was obtained from the Research Ethics Committee of the Faculty of Nursing, Mansoura University, to carry out the study.

- An oral approval was obtained from parents who accompanied the participated children after explaining the objective of the study.

- The parents were informed that all the collected data will be anonymous and will be treated confidentially.

- The researcher confirmed that the study participants will not be exposed to any form of physiological or psychological harm throughout the process of data collection.

- $\quad$ The parents were assured that it is voluntary participation and they have the right to retreat at any time from the study with no responsibility. 


\section{Data Collection Procedure}

This was a multi-day crosssectional study that was conducted from December 2015 to December of 2016 at the mentioned settings. All children who met the criteria and visited the prepared settings were included in the study. The researcher started by introducing herself to each child and the parent/caregiver in a friendly and conversational voice tone, then gave them a brief idea about the aim and nature of the study to encourage and reinforce them.Each child with his/her parent was met individually by the researcher to collect the necessary demographic data and demonstrating the social-emotional and adaptive behavior scales of Bayley-III scales. The scales were applied according to the steps of the interview questionnaires; the socialemotional scale and the adaptive behavior scale. Finally, each child was given a total score according to the

\section{Results}

Figure 1.Sex distribution among the studied children scales` scoring rules. For the socialemotional scale; regardless of the child's age, start with item 1, then completing each item until reaching the child's agesuitable stop point as pointed out in the scale and noted within the section by scoring $0,1,2,3,4$ or 5 for each item. After that, the total score was calculated then converted to a scaled score then composite score by using certain tables of the Bayley III scales. For the adaptive behavior scale; all the items must be completed, by scoring $0,1,2$, or 3 for each item, except three skill areas for children whose ages less than 12 months which are; functional pre-academics, home living, and community use. After that the total row score will be calculated at the end of each item, then the score converted to scaled score then composite score by using certain tables of the Bayley-III scales.

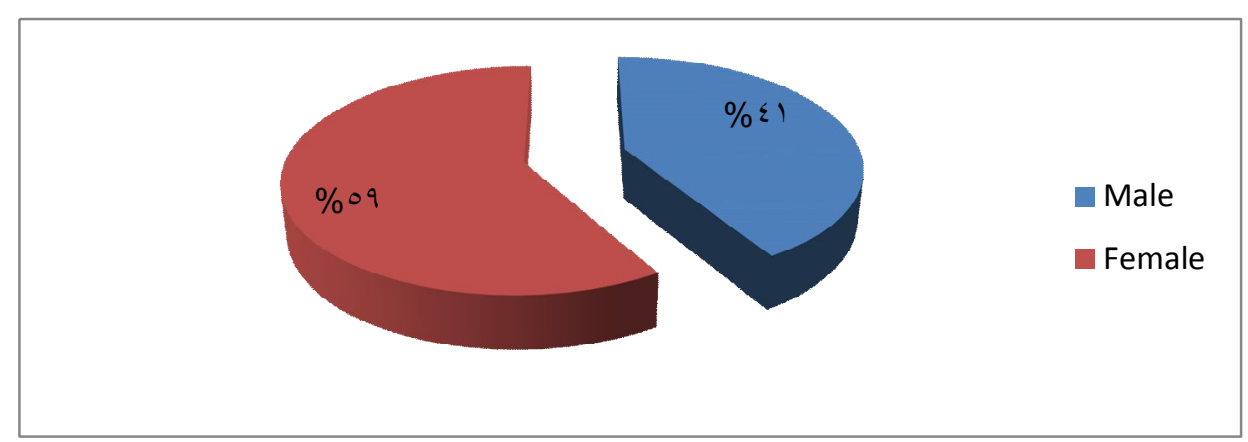

Figure (1) shows that less than two thirds $(59 \%)$ of the studied children were females, while $41 \%$ of them were males.

Table (1) proved that; the studied childrenobtained the highest mean composite score of $115.76 \pm 14.07$ in the items of the social-emotional scale than the general adaptive composite of $105.21 \pm 13.12$. 
Eman Fathy Mohamed Nofal et. al.

Table 1. Mean and standard deviation of the social-emotional scale and the adaptive Behavior of the Bayley-IIIscales for the studied children $(n=140)$.

\begin{tabular}{|c|c|c|}
\hline The items & Mean \pm SD & Min-Max \\
\hline \multicolumn{3}{|c|}{ Row score } \\
\hline Social-emotional scale & $103.71 \pm 41.04$ & $11.00-269.00$ \\
\hline Adaptive Behavior scale & & \\
\hline Communication & $35.07 \pm 18.45$ & $10.00-75.00$ \\
\hline Community use & $32.01 \pm 17.71$ & $4.00-65.00$ \\
\hline Functional pre-academic & $15.26 \pm 13.26$ & $1.00-62.00$ \\
\hline Home living & $40.62 \pm 18.45$ & $3.00-73.00$ \\
\hline Health and safety & $31.80 \pm 19.40$ & $5.00-68.00$ \\
\hline Leisure & $36.20 \pm 16.14$ & $9.00-75.00$ \\
\hline Self-care & $37.07 \pm 18.74$ & $4.00-70.00$ \\
\hline Self-direction & $35.65 \pm 19.28$ & $9.00-72.00$ \\
\hline Social & $38.17 \pm 17.42$ & $8.00-70.00$ \\
\hline Motor & $44.71 \pm 23.81$ & $6.00-81.00$ \\
\hline \multicolumn{3}{|c|}{$\begin{array}{l}\text { Composite score } \\
\end{array}$} \\
\hline Social-emotional scale & $115.76 \pm 14.07$ & $60-145$ \\
\hline General adaptive composite & $105.21 \pm 13.12$ & $68-133$ \\
\hline
\end{tabular}

Note. SD: standard deviation, Min: the compared with the USA composite score minimum score a child got, Max: the maximum score a child got

It is evident from table (2) that, the current study composite scores of the social-emotional scale and adaptive Behavior of the Bayley-IIIitems of the studied children were higher when results, which revealed statistically significant differences at $\mathrm{p}$-value $<0.001$, as the mean composite score of the current studyfor the social-emotional scale, was $115.76 \pm 14.07$, while the USA composite score of all the scales was $100 \pm 15$.

Table 2. The difference between children 's scores in the current study and those in a study conducted in the USA as regarding the social-emotional and the adaptive Behavior of the Bayley-IIIcomposite scores.

\begin{tabular}{|l|c|c|c|c|}
\hline \multirow{2}{*}{ The items } & \multicolumn{2}{|c|}{ Mean \pm SD of composite scores } & \multirow{2}{*}{ t-test } & \multirow{2}{*}{ p-value } \\
\cline { 2 - 4 } & $\begin{array}{c}\text { The current study } \\
\mathbf{N}=\mathbf{1 4 0}\end{array}$ & $\begin{array}{c}\text { USA } \\
\mathbf{N}=\mathbf{1 4 0 0}\end{array}$ & & \\
\hline Social-emotional scale & $\mathbf{1 1 5 . 7 6} \pm \mathbf{1 4 . 0 7}$ & $\mathbf{1 0 0} \pm \mathbf{1 5}$ & 3.771 & $<\mathbf{0 . 0 0 1 * *}$ \\
Generaladaptive composite & $105.21 \pm 13.12$ & $100 \pm 15$ & 3.639 & $<0.001^{* *}$ \\
\hline
\end{tabular}

Note. SD: standard deviation, (**) Highly statistically significant at $p$ $<0.001$

Comparing the study two gender, table (3) showed that the mean andSD of the row scores of the social-emotional and adaptive behaviorscalesof the Bayley-III scales of participated boys ( $\mathrm{n}$ $=58)$ are higher than that of the girls $(\mathrm{n}=$ 82 ), and the highest mean row score $109.83 \pm 40.96$ in the social-emotional scale. On the other hand, the mean and SD of thecomposite scores of the studied girls were higher than that of the boys and the highest mean composite score $116.46 \pm 15.28$ was found among the social-emotional scale. These findings revealed no significant statistical difference between the studied children of both genders regarding the mean and $\mathrm{SD}$ of the row score and composite score. 
Table 3. The difference among demographic characteristics of the studied children according to their gender as to their social-emotional scale and the adaptive Behavior scale of the Bayley-III scales mean row score and mean composite score $(n=140)$.

\begin{tabular}{|c|c|c|c|c|}
\hline \multirow[t]{2}{*}{ The items } & \multicolumn{2}{|c|}{ Gender } & \multicolumn{2}{|c|}{ Test of significance } \\
\hline & Boy $(n=58)$ & $\operatorname{Girl}(n=82)$ & t-test & p-value \\
\hline \multicolumn{5}{|c|}{ Mean \pm SD of row scores } \\
\hline Social-emotional scale & $109.83 \pm 40.96$ & $99.37 \pm 40.79$ & 1.490 & 0.138 \\
\hline $\begin{array}{l}\text { Adaptive Behavior scale } \\
\text { Communication } \\
\text { Community use } \\
\text { Functional pre-academic } \\
\text { Home living } \\
\text { Health and safety } \\
\text { Leisure } \\
\text { Self-care } \\
\text { Self-direction } \\
\text { Social } \\
\text { Motor }\end{array}$ & $\begin{array}{l}36.63 \pm 19.01 \\
35.97 \pm 17.65 \\
18.21 \pm 15.42 \\
43.70 \pm 18.78 \\
33.06 \pm 19.90 \\
38.22 \pm 16.89 \\
39.27 \pm 19.17 \\
37.86 \pm 20.16 \\
40.03 \pm 17.98 \\
47.18 \pm 24.35\end{array}$ & $\begin{array}{l}33.96 \pm 18.07 \\
29.08 \pm 17.36 \\
13.08 \pm 11.07 \\
38.34 \pm 18.05 \\
30.91 \pm 19.12 \\
34.78 \pm 15.54 \\
35.52 \pm 18.38 \\
34.08 \pm 18.60 \\
36.86 \pm 17.00 \\
42.96 \pm 23.41\end{array}$ & $\begin{array}{l}0.844 \\
1.818 \\
1.809 \\
1.346 \\
0.646 \\
1.245 \\
1.168 \\
1.143 \\
1.060 \\
1.035\end{array}$ & $\begin{array}{l}0.400 \\
0.073 \\
0.074 \\
0.182 \\
0.520 \\
0.215 \\
0.245 \\
0.255 \\
0.291 \\
0.303\end{array}$ \\
\hline \multicolumn{5}{|c|}{ Mean \pm SD of composite score } \\
\hline $\begin{array}{l}\text { Social-emotional scale } \\
\text { General adaptive composite }\end{array}$ & $\begin{array}{c}114.76 \pm 12.22 \\
104.38 \pm 14.60\end{array}$ & $\begin{array}{l}\mathbf{1 1 6 . 4 6} \pm \mathbf{1 5 . 2 8} \\
105.80 \pm 12.03\end{array}$ & $\begin{array}{l}0.705 \\
0.632\end{array}$ & $\begin{array}{l}0.482 \\
0.529\end{array}$ \\
\hline
\end{tabular}

Note. SD: standard deviation, (*) Statistically significant at $p<0.05,(* *)$ Highly statistically significant at $p$ $<0.001$

It is clear from the table (4) that, the studied children regarding their three age groups, the studied children who

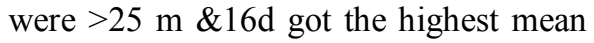
row score $157.65 \pm 24.54$ in the socialemotional scale than the adaptive Behavior scale with its items, in the same time they got the highest mean general adaptive composite score. While the children who were $13 \mathrm{~m} \& 16 \mathrm{~d}$ to $25 \mathrm{~m}$ \&15d got the highest composite score $118.90 \pm 14.02$ on the social-emotional scale. Furthermore, there was a highly significant statistical difference between the age of the participated children and all items of the social-emotional and the adaptive behaviorscales items, while there wasn tastatistically significant difference between the age of the studied children and the mean composite of the social-emotional scale $(p=0.247)$ and the general adaptive composite $(\mathrm{p}=0$. 439). 
Eman Fathy Mohamed Nofal et. al.

Table 4. The difference among demographic characteristics of the studied children according to their age in months as regarding their social-emotional scale and the adaptive Behavior scale of the Bayley-III scales mean row score and mean composite score $(n=140)$.

\begin{tabular}{|c|c|c|c|c|c|}
\hline \multirow{2}{*}{ The items } & \multicolumn{3}{|c|}{ Age in months } & \multicolumn{2}{|c|}{ Test of significance } \\
\hline & $<13 \mathrm{~m} \mathrm{\&} 15 \mathrm{~d}$ & $\begin{array}{c}13 m \& 16 d \text { to } 25 \\
\text { m \& } 15 d\end{array}$ & $>25 \mathrm{~m} \mathrm{\& 16} \mathrm{d}$ & $\begin{array}{c}\text { ANOVA } \\
\text { test }\end{array}$ & p-value \\
\hline \multicolumn{6}{|c|}{ Mean \pm SD of row score } \\
\hline $\begin{array}{l}\text { Social-emotional } \\
\text { scale }\end{array}$ & $67.75 \pm 12.90$ & $1.03 \pm 13.23$ & $157.65 \pm 24.54$ & 330.792 & $\begin{array}{l}<0.001 \\
* *\end{array}$ \\
\hline $\begin{array}{l}\text { Adaptive Behavior } \\
\text { scale } \\
\text { Communication } \\
\text { Community use } \\
\text { Functional } \\
\text { pre-academic } \\
\text { Home living } \\
\text { Health and safety } \\
\text { Leisure } \\
\text { Self-care } \\
\text { Self-direction } \\
\text { Social } \\
\text { Motor }\end{array}$ & $\begin{array}{l}11.28 \pm 5.12 \\
13.75 \pm 8.78 \\
20.73 \pm 6.61 \\
19.63 \pm 9.61 \\
17.88 \pm 7.49 \\
21.76 \pm 7.17 \\
20.78 \pm 9.87\end{array}$ & $\begin{array}{c}36.75 \pm 10.91 \\
36.75 \pm 10.91 \\
40.87 \pm 9.37 \\
41.27 \pm 9.61 \\
38.60 \pm 9.51 \\
41.90 \pm 9.14 \\
54.20 \pm 11.52\end{array}$ & $\begin{array}{c}55.32 \pm 11.17 \\
53.95 \pm 8.78 \\
54.75 \pm 5.66 \\
59.05 \pm 6.17 \\
59.35 \pm 8.88 \\
59.07 \pm 6.63 \\
71.12 \pm 7.17\end{array}$ & $\begin{array}{c}70.292 \\
225.364 \\
273.782 \\
248.563 \\
288.128 \\
291.981 \\
348.462\end{array}$ & $\begin{array}{l}<0.001^{* *} \\
<0.001^{* *} \\
<0.001^{* *} \\
<0.001^{* *} \\
<0.001^{* *} \\
<0.001^{* *} \\
<0.001^{* *} \\
<0.001^{* *} \\
<0.001^{* *} \\
<0.001^{* *}\end{array}$ \\
\hline \multicolumn{6}{|c|}{ Mean \pm SD of composite score } \\
\hline $\begin{array}{l}\text { Social-emotional } \\
\text { scale } \\
\text { General } \\
\text { adaptive } \\
\text { composite } \\
\end{array}$ & $\begin{array}{l}114.67 \pm 15.72 \\
105.43 \pm 12.76\end{array}$ & $\begin{array}{l}\mathbf{1 1 8 . 9 0} \pm \mathbf{1 4 . 0 2} \\
103.18 \pm 11.28\end{array}$ & $\begin{array}{l}114.25 \pm 11.01 \\
\mathbf{1 0 6 . 9 2} \pm \mathbf{1 5 . 2 6}\end{array}$ & $\begin{array}{l}1.415 \\
0.829\end{array}$ & $\begin{array}{l}0.247 \\
0.439\end{array}$ \\
\hline $\begin{array}{l}\text { Note. m: month, } \\
\text { deviation, }(*) \text { Statis } \\
<0.05,(* *) \\
\text { significant at } p<0 \text {. } \\
\text { Table }(5) \text { re } \\
\text { row score } 106.35 \pm \\
\text { in the family of th } \\
\text { the social-emotio } \\
\text { highest, while the } \\
\text { family got the hig }\end{array}$ & $\begin{array}{l}\text { day, SD: sto } \\
\text { ically significa } \\
\text { Highly statis } \\
01 \\
\text { ealed that the } \\
5.30 \text { the secono } \\
\text { studied child } \\
\text { al scale wa } \\
\text { third child }\end{array}$ & $\begin{array}{l}\text { ndard } \\
\text { it at } p \\
\text { ically } \\
\text { mean } \\
\text { child } \\
\text { en in } \\
\text { the } \\
\text { the }\end{array}$ & $\begin{array}{l}.31 \pm 11.93 \\
\text { le but the fou } \\
\text { leral } \\
.29 \pm 16.849 . \\
\text { significant } \\
\text { ween the birt } \\
\text { ldren and the } \\
\text { iptive Behavic } \\
\text { scales mean }\end{array}$ & $\begin{array}{l}\text { tive } \\
\text { ides, the } \\
\text { tatistical } \\
\text { order of } \\
\text { ial-emotic } \\
\text { scales of } \\
\text { w scores }\end{array}$ & $\begin{array}{l}\text {-emotional } \\
\text { he highest } \\
\text { composite } \\
\text { tble shows } \\
\text { difference } \\
\text { he studied } \\
\text { hal and the } \\
\text { he Bayley- } \\
\text { and mean }\end{array}$ \\
\hline
\end{tabular}


Assessing the Social-emotional and etc...

Table 5. Association between the studied children according to their birth order and their social-emotional scale and the adaptive Behavior scale of the Bayley-III scales items mean row score and mean composite score $(n=140)$.

\begin{tabular}{|c|c|c|c|c|c|c|}
\hline \multirow{2}{*}{ Items } & \multicolumn{4}{|c|}{ Birth order } & \multicolumn{2}{|c|}{ Test of significance } \\
\hline & First & second & Third & fourth & $\begin{array}{c}\text { ANOVA } \\
\text { test }\end{array}$ & p-value \\
\hline \multicolumn{7}{|c|}{ Mean \pm SD of row scores } \\
\hline Social-emotional scale & $103.51 \pm 39.71$ & $106.35 \pm 45.30$ & $104.48 \pm 40.71$ & $84.57 \pm 26.24$ & 0.565 & 0.639 \\
\hline $\begin{array}{l}\text { Adaptive Behavior scale } \\
\text { Communication } \\
\text { Community use } \\
\text { Functional pre- } \\
\text { academic } \\
\text { Home living } \\
\text { Health and safety } \\
\text { Leisure } \\
\text { Self-care } \\
\text { Self-direction } \\
\text { Social } \\
\text { Motor }\end{array}$ & $\begin{array}{l}36.33 \pm 17.90 \\
31.56 \pm 17.94 \\
15.29 \pm 13.23 \\
40.48 \pm 19.03 \\
32.77 \pm 19.00 \\
36.71 \pm 15.86 \\
38.52 \pm 18.28 \\
36.61 \pm 19.20 \\
39.31 \pm 16.75 \\
46.40 \pm 23.43\end{array}$ & $\begin{array}{l}33.58 \pm 19.50 \\
33.07 \pm 18.93 \\
13.82 \pm 10.59 \\
39.10 \pm 19.32 \\
31.21 \pm 19.59 \\
35.23 \pm 15.95 \\
35.73 \pm 19.56 \\
34.58 \pm 19.49 \\
37.34 \pm 17.77 \\
43.86 \pm 24.04\end{array}$ & $\begin{array}{l}43.05 \pm 16.83 \\
33.03 \pm 20.50 \\
38.27 \pm 17.70 \\
37.72 \pm 19.25 \\
37.65 \pm 19.90 \\
38.72 \pm 19.02 \\
45.20 \pm 25.38\end{array}$ & $\begin{array}{l}27.57 \pm 16.00 \\
37.50 \pm 28.99 \\
12.50 \pm 12.02 \\
48.50 \pm 23.33 \\
21.57 \pm 19.10 \\
29.00 \pm 14.96 \\
30.57 \pm 17.96 \\
27.00 \pm 18.50 \\
32.71 \pm 17.27 \\
35.14 \pm 22.85\end{array}$ & $\begin{array}{l}0.635 \\
0.111 \\
0.396 \\
\\
0.284 \\
0.740 \\
0.688 \\
0.476 \\
0.659 \\
0.347 \\
0.487\end{array}$ & $\begin{array}{l}0.594 \\
0.954 \\
0.756 \\
\\
0.837 \\
0.530 \\
0.561 \\
0.700 \\
0.579 \\
0.791 \\
0.692\end{array}$ \\
\hline \multicolumn{7}{|c|}{ Mean \pm SD of composite score } \\
\hline \begin{tabular}{lc}
\multicolumn{2}{l}{ Social-emotional scale } \\
General & adaptive \\
composite &
\end{tabular} & $\begin{array}{r}113.44 \pm 13.766 \\
105.02 \pm 13.594\end{array}$ & $\begin{array}{l}116.52 \pm 15.523 \\
103.20 \pm 13.173\end{array}$ & $\begin{array}{r}\mathbf{1 1 9 . 3 1} \pm \mathbf{1 1 . 9 3} \\
107.79 \pm 11.16\end{array}$ & $\begin{array}{c}110.71 \pm 7.86 \\
\mathbf{1 1 0 . 2 9} \pm \mathbf{1 6 . 8 4 9}\end{array}$ & $\begin{array}{l}1.519 \\
1.083\end{array}$ & $\begin{array}{l}0.212 \\
0.358\end{array}$ \\
\hline
\end{tabular}

Note. SD: standard deviation, (*)

Statistically significant at $\left.p<0.05,{ }^{* *}\right)$

Highly statistically significant at $p$ $<0.001$

\section{Discussion}

It is proved from the recent studythat;less than two thirds of the studied children were females, while about two fifth of them were males. They got the highest mean and SD of the row score $(103.71 \pm 41.04)$ and composite score $(115.76 \pm 14.07)$ in the socialemotional scale of the Bayley-III scales respectively.These findings were opposite with Acton et al. (2011) results` of the composite scores of the Bayley-III scales were in contrast to the recent study as revealedin their study that Bayley-III mean composite scores were as follows: $95.9 \pm 14.1$ cognitive scale, $90.8 \pm 18$. 1 in language scale after that93.7 \pm 14.2 in motor scale. While, Johnson, Moore and Marlow (2014) in their study confirmed that; mean scores of BayleyIIIwerenoticeably higher and close to the normative mean as the cognitive mean score $96 \pm 14$ and language mean score $103 \pm 19$, respectively.
While in divergence, in Brazil, a study by Madaschi, Mecca, Macedo and Paula (2016) reported that the highest row scores was for cognitive, gross motor, fine motor, expressive language, receptive language and the social-emotional scales respectively. The researcher suggests thatthe recent study composite scores results exceeded the previously mentioned studies results considering the differences in culture, economic status, geographical location and any other factors that can affect child development.

It is evident from the present study that, the composite scores of the recent study of the normal Egyptian infants and toddlers from Mansoura city as following; the social-emotional scale $(115.76 \pm 14.07)$ and the adaptive behavior scale $(105.21 \pm 13.12)$ respectively. These results exceeded US norms which had been proved by Albers and Grieve (2007) in their study and its results confirmed that the US norms as the composite scores mean 100 and SD 15 with a highly significant difference in all the items of the scale. The researcher point of view is that although the 
difference is clear between Egypt, the USA in terms of several factors, the most important of which is the level of income as Egypt is a third world country and the means of care and services provided for child development but the scores of the Egyptians exceeded than those of USA.

The present study showed that, among the boys, the Bayley-III scales mean row scores were non-significantly higher than that of the girls in all items of the scales while, the girls' mean composite scores were higher than that of the boys with a non-significant difference as the composite scores forboys' social-emotional composite score was $(114.76 \pm 12.22)$ and girls for (116.46 \pm 15.28$)$ with P-value (0.482), while and the boys general adaptive composite score was $(104.38 \pm 14.60)$ and for girls was $(105.80 \pm 12.03)$ with P-value (0.529).These results are opposite with the results of Hua et al. (2019) as they confirmed that, the girls' composite score is higher than the boys' with a highly significant difference at (P-value 0.007).Additionally, Rademeyer and Jacklin(2013) compared thescores of boys' with the girls' and noted that generally, no significant statistical differences. The researcher point of view about the non-significant difference between the two genders related to the findings in the present study; the parents were giving the appropriate care chance for their children for development regardless the gender as best they can. Besides, during the data collection period the girls were more sociable, were interacting more friendly while the boys were bored quickly.

As regarding the current findings, the mean row score of BayleyIII scale items for the participated children was higher in the 3rd age group older than $25 \mathrm{~m}$ and $16 \mathrm{~d}$ with a very significant statistical difference between the three age groups as p-value < 0.001 . The mean composite score of the adaptive Behavior scale was high in the $3^{\text {rd }}$ age group and the mean composite score of the social-emotional scale was higher in the $2^{\text {nd }}$ age group withnosignificant statistical difference among the three age groups $(\mathrm{p}=0.247)$.

Rademeyer and Jacklin

(2013), the opposite results were found in their study in which the composite scores of children lowered with the advanced age of evaluation. Younger age groups (2-7 months) tend to have higher scores than older age groups (6-12 months). The currentfindings revealed that the mean composite score of thesocial-emotional scale $(119.31 \pm 11.93)$ was higher in the children who were the $3^{\text {rd }}$ older childandthe general adaptive composite score was (110.29 \pm 16.849$)$ were higher in $4^{\text {th }}$ order child. Also, there was no significant statistical difference among the groups of birth order in each item of the Bayley-IIIscales. These findings were similar to the findings of Ben-Itzchak, Nachshon and Zachor (2018)who emphasized that older siblings had a positive impact on their younger siblings' developmental skills. Social interaction deficits, the presence of older or younger siblings in children, and higher cognitive abilities have also contributed significantly to social and adaptive skills. The researcher argued that the results explained how the children can learn easily from siblings, encourage and imitating each other, also, the parents gained experience about caring for their children after the first and the second child.

\section{Conclusion}

It's concluded from this study that, the studied children's scores of the social-emotional scale were higher than 
the scores of the adaptive behavior scale. In comparison between the studied children's composite scores in the two scales and the USA composite scores, the participated children got composite scores higher than that of the USA. In addition, the present study confirmed that the social-emotional and adaptive behaviorscalesofBayley-III can be used to evaluate developmental consequences and can be a practicabletool for the assessment of Egyptian children's development.

\section{Recommendations}

- Health education for the children's caregivers about the importance of periodic developmental assessment for early detection of the developmental delay.

- Generalizing the study on all the Egyptian children.

- A translated and adapted version of the social-emotional and the adaptive Behavior scales of the Bayley-III to be used in future studies, that will be easy for parents to use during the assessment and giving the best score.

\section{Statement of Competing Interests} interests.

The authors have no competing

\section{References}

Acton, B. V., Biggs, W. S., Creighton, D. E., Penner, K. A., Switzer, H. N., Thomas, J. H. P., ... \& Robertson, C. M. (2011). Overestimating neurodevelopment using the Bayley-III after early complex cardiac surgery. Pediatrics: peds. 2011-0331

Aina, O. F., \& Morakinyo, O. (2005). Normative data on mental and motor development in Nigerian children. West African journal of medicine, 24(2), 151-156.

Albers, C. A., \& Grieve, A. J. (2007). Test review: Bayley, N.(2006).
Bayley-IIIscales of infant and toddler development-third edition. San Antonio, TX: Harcourt assessment. Journal of Psychoeducational Assessment, 25(2), 180-190.

Ben-Itzchak, E., Nachshon, N., \&Zachor, D. A. (2019). Having Siblings is Associated with Better Social Functioning in Autism Spectrum Disorder. Journal of abnormal child psychology, 47(5), 921-931

Conkbayir, M. (2017). Early Childhood and Neuroscience: Theory, Research and Implications for Practice(1st ed.). Bloomsbury Publishing Plc.

Hua, J., Li, Y., Ye, K., Ma, Y., Lin, S., Gu, G., \& Du, W. (2019). The reliability and validity of BayleyIII cognitive scale in China's male and female children. Early human development, 129, 71-78.

Johnson, S., Moore, T., \& Marlow, N. (2014). Using the Bayley-III to assess neurodevelopmental delay: which cut-off should be used?.

Kirchner, R. M., Martens, M. A., \&Andridge, R. R. (2016). Adaptive Behavior and development of infants and toddlers with Williams syndrome. Frontiers in psychology, 7, 598.

Kramer, J. M., Coster, W. J., Kao, Y. C., Snow, A., \&Orsmond, G. I. (2012). A new approach to the measurement of adaptive Behavior: development of the PEDI-CAT for children and youth with autism spectrum disorders. Physical \& occupational therapy in pediatrics, 32(1), 34-47

Logsdon, A. (2018). What Is the Bayley-IIIScales Test for Infant 
Eman Fathy Mohamed Nofal et. al.

\begin{tabular}{|c|c|}
\hline 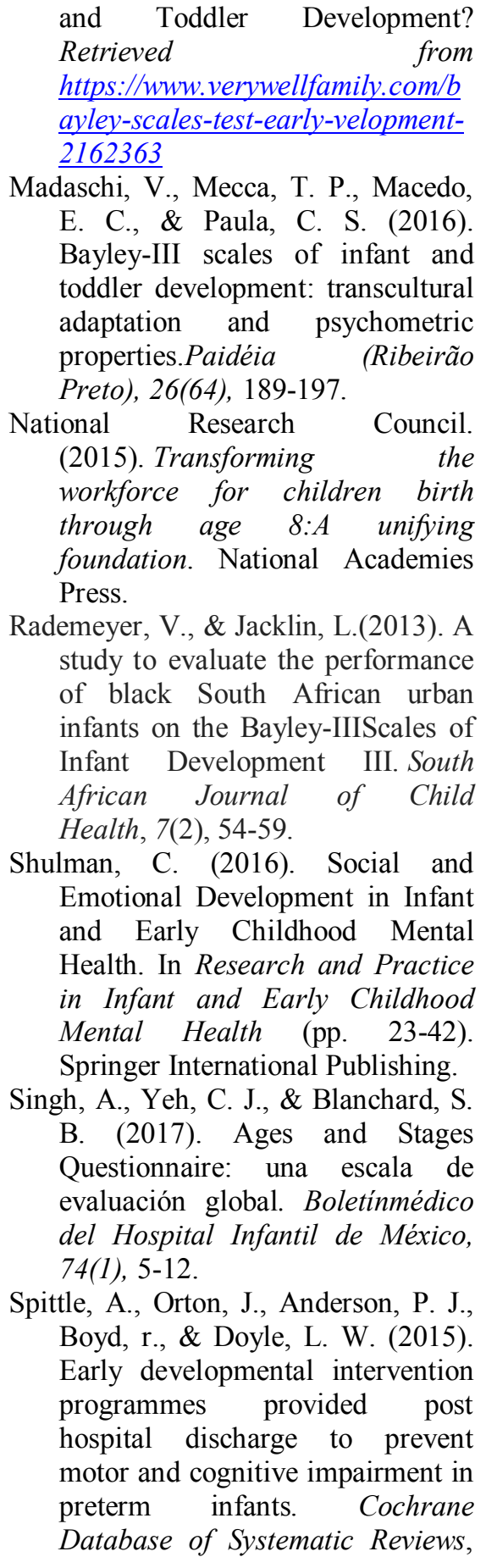 & $\begin{array}{l}\text { 11,Art.no.CD005495.doi:10.1002/ } \\
\text { 14651858.CD005495.pub4. } \\
\text { Torras-Mañá, M., Gómez-Morales, A., } \\
\text { González-Gimeno, I., Fornieles- } \\
\text { Deu, A., and Brun-Gasca, C. } \\
\text { (2016)Assessment of cognition } \\
\text { and language in the early diagnosis } \\
\text { of autism spectrum disorder: } \\
\text { usefulness of the Bayley-IIIScales } \\
\text { of infant and toddler development, } \\
\text { third edition. Journal of } \\
\text { Intellectual Disability Research, } \\
\text { 60: 502-511. } \\
\text { Veiga De Góes, F., Dalva, M., Méio, } \\
\text { B. B., Reis De Mello, R., } \\
\text { \&Morsch, D. (2015). Evaluation } \\
\text { of neurodevelopment of preterm } \\
\text { infants using Bayley-IIIIII scale } \\
\text { Avaliação do } \\
\text { neurodesenvolvimentoemlactentes } \\
\text { pré-termosusandoaescalaBayley- } \\
\text { IIIIII. Rev. Bras. SaúdeMatern. } \\
\text { Infant., Recife, 15(1), 47- } \\
\text { 55.https://doi.org/10.1590/S1519- } \\
\text { 38292015000100004. } \\
\text { Weiss, L. G., Oakland, T., \& Aylward, } \\
\text { G. P. (Eds.). (2010). Bayley-III } \\
\text { clinical use and interpretation. } \\
\text { Academic Press. } \\
\text { Yi, Y. G., Sung, I. Y., \& Yuk, J. S. } \\
\text { (2018). Comparison of Second and } \\
\text { Third Editions of the Bayley- } \\
\text { IIIScales in Children With } \\
\text { Suspected Developmental } \\
\text { Delay. Annals of rehabilitation } \\
\text { medicine, 42(2), } 313 .\end{array}$ \\
\hline
\end{tabular}

